\title{
Renal dysplasia in a Boxer dog: case report
}

[Displasia renal em um cão Boxer: relato de caso]

\author{
K.B. Brum ${ }^{1}$, R.S. Juliano ${ }^{2}$, M.A. Souza ${ }^{3}$, L.F.F. Fleury ${ }^{4}$, A.D. Damasceno ${ }^{5}$ \\ ${ }^{1}$ Departamento de Patologia - CCBS - UFMS \\ Caixa Postal 549 \\ 79070-900 - Campo Grande, MS \\ ${ }^{2}$ Embrapa Pantanal - Corumbá, MS \\ ${ }^{3}$ Universidade Federal de Mato Grosso - Cuiabá, MT \\ ${ }^{4}$ Faculdade de Medicina - UFG - Goiânia, GO \\ ${ }^{5}$ Escola de Veterinária - UFG - Goiânia, GO
}

\begin{abstract}
A 20-month-old female Boxer dog presented significant increase on the bilateral volume of the maxillaries. The necropsy revealed that the kidneys were reduced in size, pale, with lobular aspect, and reduced cortical-medullar ratio. The maxillaries cutting surface revealed trabecular aspect of brownreddish color. In addition, the lesions observed by microscopy (asynchronic differentiation of nephrons, persistent mesenchyme, and atypical tubular epithelium) allowed establishing the diagnosis of renal dysplasia with secondary fibrous osteodystrophy.
\end{abstract}

Keywords: dog, fibrous osteodystrophy, renal dysplasia

\section{RESUMO}

Uma cadela Boxer com 20 meses de idade apresentou grande aumento de volume bilateral nos maxilares. À necropsia, os rins apresentavam-se diminuidos de tamanho, pálidos, com aspecto lobular e relação córtico-medular reduzida. A superficie de corte dos maxilares revelou aspecto trabecular de coloração marrom-avermelhada. As lesões observadas à microscopia (diferenciação assincrônica de néfrons, mesênquima persistente e proliferação tubular atípica) permitiram estabelecer o diagnóstico de displasia renal com osteodistrofia fibrosa secundária.

Palavras-chave: cão, osteodistrofia fibrosa, displasia renal

\section{INTRODUCTION}

Renal dysplasia is defined as the disorganized development of renal parenchyma due to the abnormal tissue differentiation. In most cases, it is characterized by the presence of inadequate structures for the stage of development of the organism or the development of abnormal structures (Maxie, 1993; Lees, 1996). It is a common cause of renal insufficiency in dogs, being described in the following breeds: Lhasa Apso, Shih Tzu, Great Dane, Samoyed, Alaskan Malamute, King Charles Spaniel, Bulldog (Picut and Lewis, 1987), Labrador Retriever (Sarkiala et al., 1994), Rhodesian Ridgeback (Lobetti et al., 1996), Boxer and Finnish Harriers (Hoppe and Karlstam, 2000), Boxer, Rottweiler, Collie, and Irish Wolfhound (Peeters et al., 2000).

Nephrogenesis is incomplete at birth in dogs and cats, reason why displasic alterations may occur due to infections occurred at the neonatal period in function of the canine herpes virus (Maxie, 1993). A genetic study carried out with Shih tzu dogs suggested that the renal dysplasia in this breed would be hereditary and transmitted by a simple autossomic recessive gene (Hoppe et al., 1990). Some authors believe that the same occurs

Recebido em 29 de outubro de 2007

Aceito em 2 de setembro de 2008

E-mail:kbbrum@nin.ufms.br 
in Lhasa Apso dogs (O’Brien et al., 1982). There are evidences that this disease in Standard Poodle, Soft-coated Wheaten Terrier, Golden Retriever, Alaskan Malamut, and Chow Chow dogs has also a genetic origin (Lees, 1996).

The age of the diseased animals ranged from one month to 10 years (Picut and Lewis, 1987; Hoppe et al., 1990; Lees, 1996; Hoppe and Karlstam, 2000), but in general, the clinical evidences start being observed before the animal reaches the age of two years (Hoppe et al., 1990; Lees, 1996; Hoppe and Karlstam, 2000).

Main clinical evidences are those of the chronic renal insufficiency characterized by polyuria, polydipsia, lethargy, reduced appetite, weight loss, and vomiting. The animals may also present dehydration, anemia, oral ulcerations, and halitosis. A frequent outcome is the development of secondary hyperparathyroidism (Lazaretti et al., 2006) and renal lesion, which may originate skeletal deformations (fibrous osteodystrophy) that often affects the face bones most prominently (Lees, 1996).

Brown tumor is a localized form of fibrous osteodystrophy observed in patients with hyperparathyroidism due to alterations on the normal regulation of the bone osteoblastic/osteoclastic activity. Its name is derived from the brown coloration at the cutting surface observed by macroscopy, as a result of the presence of hemorrhage areas and hemosiderin deposits (Sanromán et al., 2005).

Primary histological alterations that lead to renal dysplasia in dogs include asynchronic differentiation of nephrons, persistent mesenchyme, persistent metanephric ducts, atypical tubular epithelium, and dysontogenic metaplasia. Compensatory lesions, such as hypertrophy and hyperplasia of glomerular tufts and tubules, may also be observed, as well as several types of degenerative and inflammatory lesions (Picut and Lewis, 1987).

This paper describes a case of renal dysplasia with significant fibrous osteodystrophy brown tumor type in the maxillaries of a female Boxer dog.

\section{CASE REPORT}

A 20-month-old female Boxer dog presented significant increase on the bilateral volume of the maxillaries for approximately two months, according to report from its owner, and was referred to the veterinary hospital. Head radiography and blood collection were taken for blood count and urea and creatinine evaluations.

Radiographic examination revealed intense bone demineralization in the cranium. The blood count result indicated non-regenerative anemia. High urea $(196 \mathrm{mg} / \mathrm{dl})$ and creatinine $(4.7 \mathrm{mg} / \mathrm{dl})$ values were detected. After analysis of these results, euthanasia was recommended. Unfortunately, it was not possible to evaluate the family background of the animal.

The dog presented the following symptoms: cachexia, jaundice, dehydration, and also ectoparasites. The alteration that most attracted attention during necropsy was the presence of a large and bilateral mass of firm consistency at the maxillaries (Fig. 1), but without resistance to the cut with knife, associated to the loss of teeth and ulcerations in the oral cavity. The maxillaries cutting surface presented trabecular aspect of brown-reddish color (Fig. 2). The kidneys were reduced in size and pale, with lobular aspect and firm consistence when cut. Multifocal fibrosis areas and reduced cortical-medullar ratio were also observed (Fig. 3). Cysts were not present in renal tissue.

Organ fragments collected at the necropsy were fixed in $10 \%$ neutral buffered formalin, processed for paraffin inclusion, cut, and stained with hematoxylin and eosin (HE). The Masson Tricome staining method was also performed in renal tissue fragments.

Microscopic alterations were observed in the kidneys and in the maxillary mass. The kidneys presented reduced amount of glomerules; asynchronic differentiation of nephrons, characterized by the presence of immature glomerules (Fig. 4) and tubules (Fig. 5) (flat cells with scarce cytoplasm) diffusely distributed at the cortical region; and dilated collecting ducts. Atypical tubular epithelium with adenomatoid 
proliferation of cuboidal epithelium within the expanded lumen of some collecting ducts surrounded by persistent mesenchyme (Fig. 6) was observed (negative for Masson Tricome staining method). Compensatory lesions such as hypertrophy and hyperplasia of glomerular tufts were also observed.

Degenerative alterations such as moderate diffuse cortical interstitial fibrosis (Fig. 5), evidenced by the Masson Tricome staining method, reached the cortical-medullar junction and occasionally formed radial segments originated from the sub-capsular region. Proliferation of the periglomerular fibrous tissue and atrophy of some glomerules were verified. The presence of non-suppurative interstitial nephritis from multifocal to focally extensive and accentuated was observed, which was more concentrated at the conjunctive septa region. Other degenerative alterations could be observed such as cystic glomerular atrophy (Fig. 4), characterized by the cystic dilation of the Bowman capsule, with atrophy of the glomerular tuft and small focus of calcification on the wall of some isolated tubules in the cortical.

Histologically, the mass found at the maxillaries presented bone reabsorption areas with the presence of numerous multinucleated giant cells and proliferation of conjunctive tissue associated to congestion and diffuse hemorrhage and small hemosiderin multifocal deposits, which characterizes a lesion known as brown tumor.

Clinical and anatomical-pathological report presented allowed establishing the diagnosis of unknown etiology renal dysplasia with intense fibrous osteodystrophy, probably as the outcome of secondary hyperparathyroidism.

\section{DISCUSSION}

Etiology of renal dysplasia is still unknown in most dog breeds (Maxie, 1993), and in only a few breeds, the familiar factor was verified (O’Brien et al., 1982; Hoppe et al., 1990). In the present case, the cause determination was even more impaired because it was not possible to evaluate the familiar background of the animal.

Macro and microscopic alterations observed in this animal have been described in several other cases of renal dysplasia in dogs (Picut and
Lewis, 1987; Lobetti et al., 1996; Hoppe and Karlstam, 2000; Peeters et al., 2000), although there are few reports including Boxer dog (Hoppe and Karlstam, 2000; Peeters et al., 2000).

Definitive diagnosis of renal dysplasia should be performed based on the presence of characteristic lesions (Lees, 1996). Picut and Lewis (1987) proposed five criteria as primary renal dysplasia alterations in dogs. The dog described in this study presented three of them (asynchronic differentiation of nephrons, persistent mesenchyme, and atypical tubular epithelium), which were sufficient for the establishment of the renal dysplasia diagnosis, while the other criteria (persistent metanephric ducts and dysontogenic metaplasia) were not observed. Thus, the persistent metanephric ducts are associated to the presence of cysts commonly observed by macroscopy; fact that did not occur in the dog of the present study and the dysontogenic metaplasia (osseous and cartilaginous) is seldom observed in dogs. Both alterations are commonly observed in cases of renal dysplasia in humans, but are not common in dogs (Picut and Lewis, 1987).

Degenerative, inflammatory, and compensatory lesions observed in this animal are described in cases of renal dysplasia (O'Brien et al., 1982; Hoppe et al., 1990; Lobetti et al., 1996; Hoppe and Karlstam, 2000; Peeters et al., 2000); however, they are not specific and may also occur in other diseases involving the renal function (Picut and Lewis, 1987; Bueno de Camargo et al., 2006).

Characteristic clinical evidences of renal insufficiency in dogs described in other cases of renal dysplasia (Lees, 1996; Peeters et al., 2000) have not been reported by the owner of the dog described in this study, despite the seriousness of the lesions observed at both necropsy and histological examination.

Macro and microscopic lesions observed in the maxillaries were similar to those described in other cases of fibrous osteodystrophy brown tumor type (Norrdin, 1975; Sanromán et al., 2005). In most cases, the brown tumor appears as a result of the secondary hyperparathyroidism in patients with chronic renal insufficiency (Sanromán et al., 2005). 


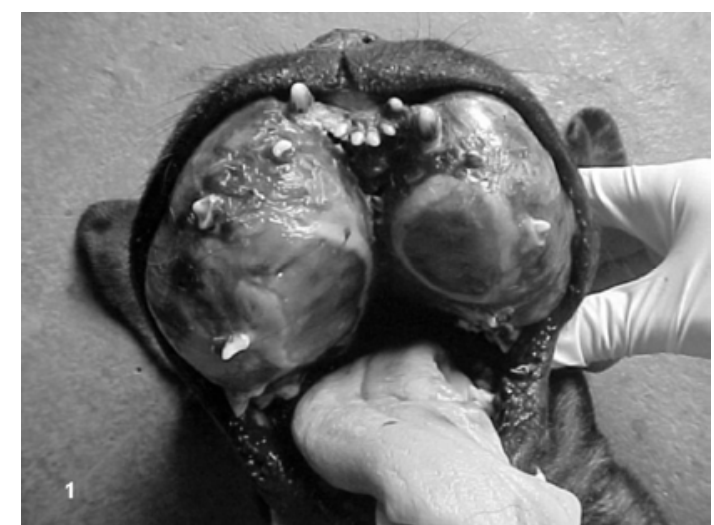

Figure 1. Maxillaries. Boxer dog. Large and bilateral mass of firm consistency at the maxillaries, but without resistance to the cut with knife, associated to the loss of teeth and ulcerations in the oral cavity.

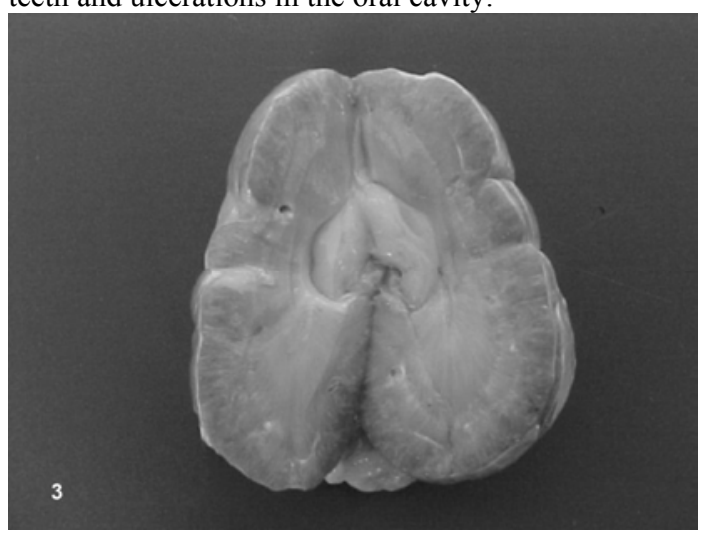

Figure 3. Kidney; Boxer dog. Reduced in size, pale, with lobular aspect, firm consistence when cut, showing multifocal fibrosis areas and reduced cortical-medullar ratio.

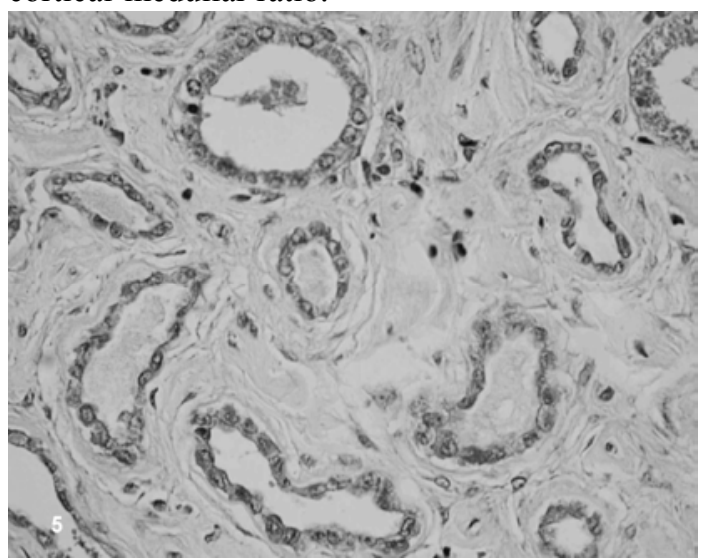

Figure 5. Kidney; renal cortical. Boxer dog. Immature tubules surrounded by interstitial fibrosis. HE, obj.40.



Figure 2. Maxillaries. Boxer dog. Cutting surface presented trabecular aspect of brown-reddish color.



Figure 4. Kidney; renal cortical. Boxer dog. Immature glomerules, difuse interstitial fibrosis, non-suppurative interstitial nephritis, and cystic glomerular atrophy. HE, obj.20.

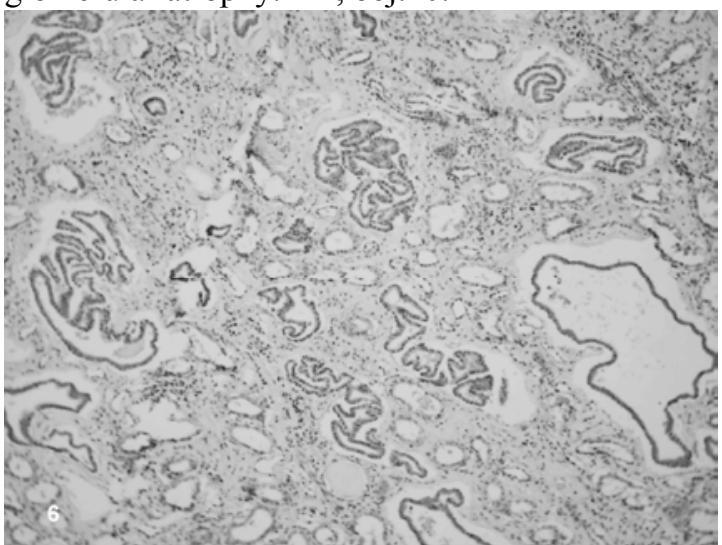

Figure 6. Kidney; renal medullar. Boxer dog. Atypical tubular epithelium with adenomatoid proliferation of cuboidal epithelium within the expanded lumen of some collecting ducts, surrounded by persistent mesenchyme. HE, obj.20. 
Chronic renal insufficiency leads to the loss of the inhibition feedback for the parathormone release, and contributes to the hyperparathyroidism development. As a result, the mobilization of the bone calcium for the calcemy maintenance increases and the osteoid tissue is replaced by conjunctive tissue, what leads to the fibrous osteodystrophy (Sarkiala et al., 1994). The parathormone serum levels were not determined in this case, but the seriousness of the observed lesions associated to the intense fibrous osteodystrophy presented were sufficient for the establishment of the secondary renal hyperparathyroidism diagnosis.

\section{REFERENCES}

BUENO DE CAMARGO, M.H.; MORAES, J.R.E.; CARVALHO, M.B. et al. Alterações morfológicas e funcionais dos rins dos cães com insuficiência renal crônica. Arq. Bras. Med. Vet. Zootec., v.58, p.781-787, 2006.

HOPPE, A.; KARLSTAM, E. Renal dysplasia in Boxers and Finnish harriers. J. Small Anim. Pract.,v.41, p.422-426, 2000.

HOPPE, A.; SWENSON, L.; JÖNSSONT, L. et al. Progressive nephropathy due to renal dysplasia in shih tzu dogs in Sweden: a clinical pathological and genetic study. J. Small Anim. Pract., v.31, p.83-91, 1990.

LAZARETTI, P.; KOGIKA, M.M.; HAGIWARA, M.K. et al. Concentração sérica de paratormônio em cães com insuficiência renal crônica. Arq. Bras. Med. Vet. Zootec., v.58, p.489-494, 2006.
LEES, G.E. Congenital Renal Diseases. Vet. Clin. North Am.: Small Anim. Pract., v.26, p.1379-1399, 1996.

LOBETTI, R.G.; PEARSON, J.; JIMENEZ, M. Renal dysplasia in a Rhodesian ridgeback dog. $J$. Small Anim. Pract., v.37, p.552-555, 1996.

MAXIE, M.G. The Urinary System. In: JUBB, K.V.F.; KENNEDY, P.C.; PALMER N. (Eds). Pathology of domestic animals. London: Academic, 1993. p.447-538.

NORRDIN, R.W. Fibrous osteodystrophy with facial hyperostosis in a dog with renal cortical hypoplasia. Cornell Vet., v.65, p.173-186, 1975.

O'BRIEN, T.D.; OSBORNE, C.A.; YANO, B.L. et al. Clinicopathologic manifestations of progressive renal disease in Lhasa Apso and Shih Tzu. J. Am. Vet. Med. Assoc., v.180, p.658-664, 1982.

PEETERS, D.; CLERCX, C.; MICHIELS, L. et al. Juvenile nephropathy in a boxer, a rottweiler, a collie and an irish wolfhound. Aust. Vet. J., v.78, p.162-165, 2000.

PICUT, C.A.; LEWIS, R.M. Microscopic features of canine renal dysplasia. Vet. Pathol., v.24, p.156-163, 1987.

SANROMÁN, J.F.; BADIOLA, I.M.A.; LÓPEZ, A.C. Tumor pardo en la sínfisis mandibular como primera manifestación clínica de hiperparatiroidismo - diagnóstico y tratamiento. Med. Oral Patol. Oral Cir. Bucal., v.10, p.169172, 2005.

SARKIALA, E.M.; DAMBACH, D.; HARVEY, C.E. Jaw lesions resulting from renal hyperparathyroidism in a young dog - a case report. J. Vet. Dent., v.11, p.121-124, 1994. 